\title{
SPONTANEOUS ORDER VERSUS CENTRAL PLANNING: A COMPARISON OF MICHAEL POLANYI \& F.A. VON HAYEK
}

\author{
PATRICK REIMERS*
}

Fecha de recepción: 15 de abril de 2019

Fecha de aceptación: 22 de junio de 2020

Abstract: This paper evaluates and compares the main philosophic and economic thoughts of the two great liberal minds Michael Polanyi and Friedrich A. von Hayek in regards to the concept of a 'spontaneous order'. In several of their books and papers, both Michal Polanyi (1941, 1948, 1951) and F.A. von Hayek (1944, 1945, 1964, 1973) strongly emphasised on the impossibility of socialism and the superiority of a free market versus public interventionism. Both highlighted their conviction that central planning cannot be more efficient than a spontaneous order, since knowledge is dispersed (Hayek) and tacit (Polanyi). Although both shared very similar concerns in regards to economic matters, they did not always come to the same conclusions. Thus, also the differences between Polanyi's and Hayek's concepts will be discussed, such as Polanyi's emphasis on defending subsystems as the basic units of society, and his focus on maximizing "public freedom". Both came to different conclusions in regards to the institutional character of science, and even concluded somewhat differently on the character of knowledge. Most importantly, they developed different concepts on political economy and the ideal role of the State. Moreover, this paper will consider the impact of $M$. Polanyi on the concept of polycentricity and on the ideas of Elinor Ostrom, while also referring to the different understanding of the role of the State in the ideas of F.A. Hayek compared to other Austrian School economists, such as Murray N. Rothbard. In addition, the paper pretends to historically analyse the emergence of the term 'spontaneous order', showing that it is not the product of one mind's design, but the consequence of the thoughts of several great minds, such as Carl Menger, Ludwig

* Patrick Reimers, MBA and Master in Austrian School Economics. Patrick is also holding an M.A. in Philosophy (Maestría en Filosofía) from Universidad Francisco Marroquín (UFM) and is currently a Ph.D. student at Universidad Rey Juan Carlos (Doctorando en Ciencias Sociales y Jurídicas). 
von Mises, F.A. von Hayek, Michael Polanyi, Walter Eucken, and Wilhelm Röpke.

Keywords: liberalism, libertarianism, capitalism, Austrian school of economics, interventionism, collectivism, spontaneous order, dynamic efficiency, free market economy, polycentricity, catallactics, extended order, tacit knowledge, dispersed knowledge, F.A. Hayek, Michael Polanyi

JEL Classification: A12, B10, B13, B25, H10, H40, K11, P10, P14, P16, P26, P48, P51

Resumen: Este artículo evalúa y compara los principales pensamientos económicos y filosóficos de las dos grandes mentes liberales Michael Polanyi y Friedrich A. von Hayek con respecto al concepto del orden espontáneo. En sus obras principales, tanto Michael Polanyi (1941, 1948, 1951) como F.A. von Hayek (1944, $1945,1964,1973$ ) destacaron fuertemente la imposibilidad del socialismo y la superioridad de un mercado libre versus el intervencionismo público. Ambos estaban convencidos de que la planificación central no puede ser más eficiente que un orden espontáneo, ya que el conocimiento es disperso (Hayek) y tácito (Polanyi). Aunque ambos compartían preocupaciones muy similares con respecto a los asuntos económicos, no siempre llegaron a las mismas conclusiones. Por lo tanto, también se discutirán las diferencias entre los conceptos de Polanyi y Hayek, como el énfasis de Polanyi en defender los sub-sistemas como unidades básicas de la sociedad y su enfoque en maximizar la "libertad pública". Ambos llegaron a conclusiones diferentes con respecto al carácter institucional de la ciencia y al carácter del conocimiento. Además, este artículo considerará sus diferentes conceptos sobre economía política y el papel ideal del Estado, y analiza el impacto de $M$. Polanyi en el concepto de policentrismo y en las ideas de Elinor Ostrom. Por otra parte, el artículo pretende analizar históricamente la aparición del término "orden espontáneo", mostrando que no es producto del diseño de una sola mente, sino la consecuencia de los pensamientos de varias grandes mentes, como Carl Menger, Ludwig von Mises, FA von Hayek, Michael Polanyi, Walter Eucken y Wilhelm Röpke.

Palabras clave: liberalismo, libertarismo, capitalismo, escuela austriaca de economía, intervencionismo, colectivismo, orden espontáneo, eficiencia dinámica, economía de libre mercado, policentrismo, orden extendido, conocimiento tácito, conocimiento disperso, F.A. Hayek, Michael Polanyi

Clasificación JEL: A12, B10, B13, B25, H10, H40, K11, P10, P14, P16, P26, P48, P51 
INTRODUCTION TO MICHAEL POLANYI AND F. A. VON HAYEK

Michael Polanyi (1891-1976), born Pollacsek Mihály in Budapest, was the fifth child of Mihály and Cecília Pollacsek, secular Jews from Ungvár. His father's family were entrepreneurs, while his mother's father was the senior teacher of Jewish history at the Vilna rabbinic seminary. Michael's older brother was Karl Polanyi, a political economist and anthropologist, and his niece was Eva Zeisel, a well-known ceramist (Grant, 2007). Elected to the Royal Society and the American Academy of Arts and Sciences, Michael Polanyi's contributions to research in the social sciences, but also his theories on knowledge are of crucial academic importance. He emigrated to Germany in 1926, becoming a chemistry professor at the Kaiser Wilhelm Institute in Berlin. When Hitler rose to political power, he went to England as professor of physical chemistry in Manchester. In England, and during World War II Michael Polanyi changed fields and became a philosopher. Unlike most thinkers who usually make their most relevant academic and scientific contributions in the discipline in which they finalized their $\mathrm{PhD}$, Michael Polanyi trained in two disciplines and even worked in three: medicine and physical-chemical research as well as philosophy, where he contributed to the formation of a new understanding of science (Jacobs, Management and Michael Polanyi's Thought, 2015). Thus, one may say that the polymath Michael Polanyi started as a physical chemist, but his interests gradually shifted to economics, politics, and philosophy, where he would ultimately further develop his theory of knowledge which had grown out of his own experience both with scientific method as well as with political totalitarianism. (Polanyi M. , Logic of Liberty. University of Chicago Press, 1951)

In the early 1940s, Polanyi was a respected natural scientist who was becoming more and more hostile towards communism, rejecting centralized public planning of science and of the market, while still supporting Keynesian macroeconomics. From 1933 to 1958, Polanyi was on the staff of Manchester University. He first occupied the chair in Physical Chemistry for fifteen years - publishing 
the last of his 218 natural scientific papers in 1949 - and then occupied a personal chair in Social Studies. In his book The Tacit Dimension (1967), strongly criticised the logical empiricism and positivism which dominated the philosophy of science in that era. Methodological subjectivism was central to the way Michael Polanyi approached most topics.

The concept of spontaneous order, on which Friedrich August von Hayek later built his theory of cultural evolution, shows obvious similarities to Michael Polanyi's corresponding writings. Polanyi concluded that all belief systems, including the hard sciences, initiate from an irreducibly personal starting point, a conviction that we have that we must not compel others to accept. Moreover, the best way for people to assure justice and progress lies in a community of freely associating people sharing the same personal convictions. Also sciences can be most successful if researching in such an open, spontaneous community. (Polanyi M., The Tacit Dimension, 1967)

Michael Polanyi as well as F.A. Hayek agreed that economic and political orders are so complex, and involve so much scattered information, that no central authority could provide the details required to design them. Polanyi argued that in complex social systems, an 'ordering' appropriate to the requirements of a permanently changing environment is only possible if sufficient freedom is given for self-determination and voluntary, mutual adaptation of the members of society. Polanyi calls the orders resulting from the voluntary and mutual adjustments between free individuals "spontaneous" or "polycentric." Maintaining order in a complex society is basically given by simply enabling people "to interact with each other on their own initiative" only being subject to certain general laws which apply to everyone. This spontaneous order concept is the essence of Michael Polanyi's connection between science and the market process.

Friedrich A. von Hayek (1899-1992) work The Road to Serfdom, published in 1944, is an anti-socialist classic, warning of the threat of tyranny resulting from government control of economic decision-making through central planning1. Written at the end of

${ }^{1}$ F.A. Hayek can be seen as the best known ambassador of the spontaneous order concept within the traditional Austrian School of economics. His book The Road to 
Hayek's long and impressive life, his book The Fatal Conceit could be seen as the ideal introduction to and summary of Hayek's most relevant views. Although addressing a wide range of topics, it mainly focused on one common theme: the nature and societal role of knowledge and information, and their corresponding use and misuse. A major theme of The Fatal Conceit is the profound critique of all forms of socialism, stating that any socialist system has been and will be "a mistake" as only a free market economy, which Hayek preferred to call an "extended order", can assure long-term prosperity and freedom. Hayek points out that the 'moral' institutions of free market capitalism, such as private property and contracts, represent the natural result of a proper evolutionary process. Hayek states that humanity, without central planning and without any conscious central designing, naturally and gradually moved towards capitalism since it represents the most efficient order (1991). Consequently, Hayek's spontaneous order is a concept of unplanned social order, generated unconsciously by goal-oriented individual action, stating that these self-organizing social phenomena are transmitting more relevant information than any centrally steered, conscious design. A minimized intervention of government must be assured, as otherwise not only individual liberties, but also cultural evolution are threatened, since freedom, liberalism and cultural evolution are closely connected. Hayek states that spontaneous order promotes cooperation, enabling individuals to coordinate their actions e.g. via market prices, and cultural rules. His crucial point is that civilization as such depends on "the extended order of human cooperation". A major threat to the prosperity of civilization and the extended order is socialism, as "socialist morality would destroy much of present humankind and impoverish much of the rest". Polanyi agreed on Hayek's idea that freedom is an essential element of coordination. He called this process of coordination polycentricity, that is, by essentially independent productive centers which distribute their products through a market. Then, Polanyi analysed the institutions which in a polycentric system 'provide the

Serfdom explained the impossibility of socialism, which he further explained in later books throughout his life. 
persons making decisions with the five factors of responsible societal action' (Polanyi, 1997, p. 189).

For this, he used the following visual explanation.

\section{CHART 1: RESOURCE ALLOCATION IN THE ECONOMIC SYSTEM}

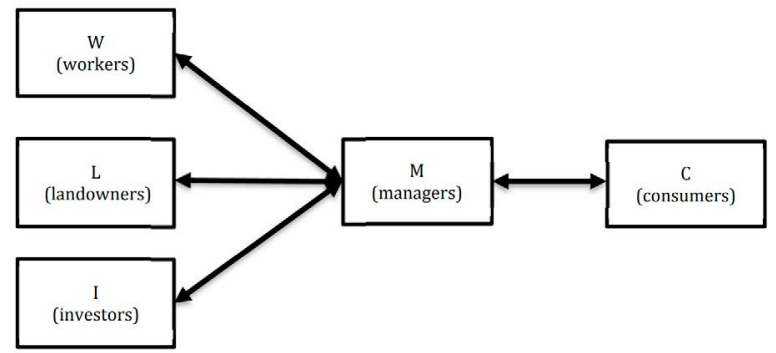

Source: Concept of M. Polanyi, chart designed by Agnès Festré

The workers (W) allocate themselves to jobs offered by managers (M), for which, to see it from the other perspective, the workers are able to perform jobs offered by managers. Similarly the landowners (L) provide land/ sites for factories/ plants steered by managers. Ultimately, the managers assure that products are being provided to the customers (C), while the customers can ultimately choose between different products allocated via the managers.

Also Michael Polanyi agreed that "the system of prices ruling the market not only transmits information in the light of which economic agents can mutually adjust their actions, it also provides them with an incentive to exercise economy in terms of money."

Hayek criticised the epistemological presumption that 'a few enlightened ones' should not only have the moral, but also legal right to reshape society, even if this potentially means disrespecting the liberties, beliefs and rights of others, by arguing that 'at the end society as a whole will benefit' from the central steering of a few. Hayek believed that people are not as good at creating and designing as they often think they were or, using Hayek's words: 
"The curious task of economics is to demonstrate to men how little they really know about what they imagine they can design" (Hayek, 1991). It is entirely wrong to believe that the culmination of a highly organized state constituted the culmination of the early development of civilisation. As a historic explanation, Hayek states that trade is older than agriculture or any other form of regular production, while in Europe there is evidence of long distance trade going back to the Palaeolithic age, approximately 30,000 years ago. Throughout the past centuries, governments have more often hampered than supported the development of (long-distance) trade. Hayek criticizes the dangerous illusion that "man is able to shape the world around him according to his wishes." We may identify the three main modern evolutionary economic schools, namely the Austrian School, neo-Schumpeterians, and institutionalists (see Chart 1). The arrows indicate the main influences of the different authors and researchers.

CHART 2: EVOLUTIONARY ECONOMICS AND MUTUAL INFLUENCES OF ECONOMICS, SOCIAL SCIENCES, AND BIOLOGY

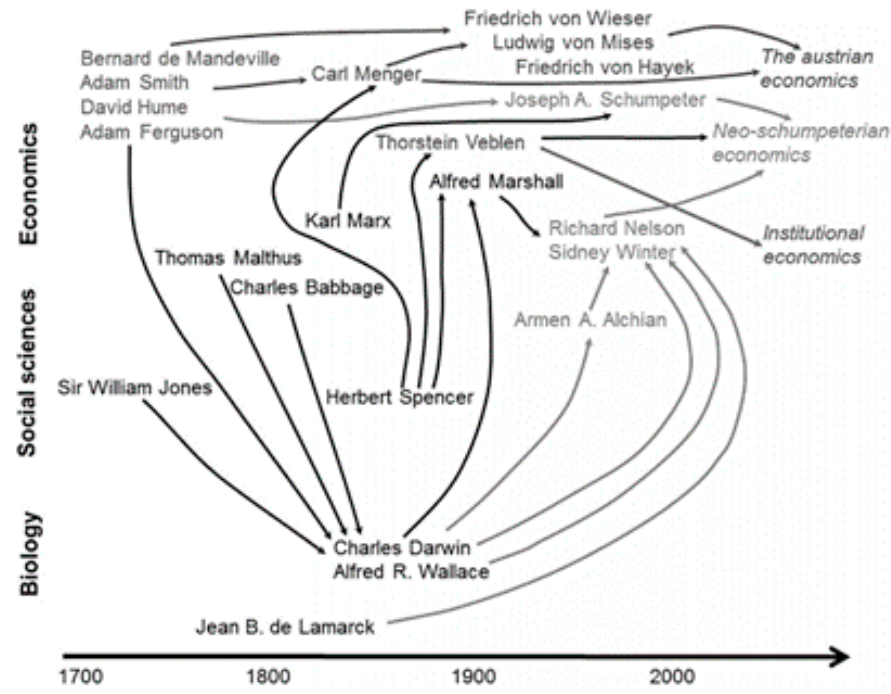

Source: Design by Witold Kwasnicki 
II HAYEK AND THE INEFFICIENCY OF CENTRAL PLANNING

Hayek proves the inefficiency and the lack of moral or economic justification of all forms of Socialism, as socialist ideas are not only incorrect from a logical perspective, but also stating that the premises used by socialists to form their arguments are incorrect, too. There is no effective way to combine and detect the astronomical quantity of information needed to direct economic resources of specific applications properly. There is not one person, not one computer or government, that can contain all of the relevant knowledge necessary to detect all scarcity ratios of all goods and services within a certain economy, and will therefore never be able to define new business models, niches, necessities and inventions as quickly and properly as the free market does. Hayek defended that only calculation and distribution in terms of market prices enable us to utilise discoverable resources intensively. One of Hayek's main arguments can be found on page 108 of The Fatal Conceit: "imagining that all order is the result of design, socialists conclude that order must be improvable by better design of some superior mind." Hayek stated that "in the marketplace, unintended consequences are common, as the distribution of resources is affected by impersonal processes in which individuals, acting for their own ends, do not know what will be the net result of their actions". He also criticized the presumption to think individuals, no matter how intelligent they are, could fully understand and efficiently guide other individuals.

Also, culture and society are not the product of human reasoning. The opposite is true as it is our culture and the evolution of society that defined our reasoning. Consequently, also due to people's ignorance, political power of governments must be minimized in order to assure progress, prosperity and respectful interaction within society. Since modern civilization with its customs and traditions, led to the current order in a natural way, any fundamental changes to the existing system, trying to control 'society', 'citizens' or 'consumers' must eventually fail. Hayek mentions how order rises from chaos naturally through competition (survival of the fittest). 
"To the naive mind that can conceive of order only as the product of deliberate arrangement, it may seem absurd that...order can be achieved more effectively by decentralizing decisions....The alterable division of the power of disposal over particular resources among many individuals...obtained through individual freedom and several property makes the fullest exploitation of dispersed knowledge possible" -F. A. Hayek, The Fatal Conceit

Like morality, law, language and biological organisms, also monetary institutions result from spontaneous order. Financial institutions can be seen as some of the most abstract institutions of an advanced civilisation, on which trade heavy depends, the moment barter is replaced by indirect exchange mediated by money. Under government control, the current monetary system has become more complex and more artificial, not being driven by true offer and demand.

The "spontaneous order," Hayek argued, is a dynamic discovery process, in which people can experiment with new social mores, or new laws, just as they might with new technologies. As he put it in The Constitution of Liberty, "the existence of individuals and groups simultaneously observing partially different rules provides the opportunity for the selection of more effective ones."

This definition is very close to the explanations given by Michael Polanyi:

"A free society is regarded as one that does not engage, on principle, in attempting to control what people find meaningful, and a totalitarian society is regarded as one that does, on principle, attempt such control..... When order is achieved among human beings by allowing them to interact with each other on their own initiative - subject only to the laws which uniformly apply to all of them - we have a system of spontaneous order in society." Michael Polanyi, The Logic of Liberty (1951)

Hayek and Polanyi agreed that in a socialist system, the allocation and use of means of production will always be less effective than the free market, and it must ultimately fail as there is no rational, valid means of economic calculation to allocate scarce resources efficiently, as in previous works already explained by 
Ludwig von Mises $^{2}$ and later on as well by M. Rothbard and I. Kirzner ${ }^{3}$.

III

\section{HAYEK ON THE EXTENDED ORDER AND CATALLACTICS}

The importance of the extended order is stated by Hayek when he argues that "..our civilization depends, not only for its origin but also for its preservation, on what can be precisely described only as the extended order of human cooperation, an order more commonly, if somewhat misleadingly, known as capitalism" (The Fatal Conceit, 1989, p. 6). The extended order of human cooperation plays a central role in Hayek's beliefs, which need to be understood and respected, to maximize prosperity and freedom of mankind. Hayek defines the "extended order" as a society based on a voluntary exchange within a free market, with limited government, property rights, and the Rule of Law. The extended order can be seen as a species of the "spontaneous order" process, being the result of human action but not of human design.

The basis of spontaneous order is that a stable and effective form of relationship can develop from evolved rules. These rules can be implicit not explicit, and might not even be rationally justified. They develop without any conscious central planning and steering. Taking the examples of money, law and language, all major aspects which have shaped most civilizations throughout decades or centuries were caused by the spontaneous order process. The most important one of all such spontaneous orders is the extended order. Both, the evolution of the common law, as

${ }^{2}$ Ludwig von Mises and F.A. Hayek can both be seen as the best-known Austrian school economists, who delivered evidence of the impossibility of socialism, and the inefficiency of public central planning. These concepts were thoroughly discussed in their magnum opuses/ magna opera Human Action (Mises) and The Fatal Conceit (Hayek).

3 The book Competition and Entrepreneurship (1973) by Israel M. Kirzner can be seen as the further development of Hayek's ideas in regards to a dynamic, constantly changing market, in which entrepreneurs need to be alert and creative, detecting market niches and customer demands. 
well as the evolution of the barter economies towards monetary economies can be seen as components of extended order. To explain the concept and nature of the extended order, Hayek distinguishes between three forms of "morals", while morals could be better described as cultural norms, traditions or even explicit ethical systems: a.) instinctive morals, b.) evolutionary morals, and c.) rationalistic morals. These three forms differ in culture and or the corresponding socioeconomic system. Moreover, Hayek noted that the extended order's evolution arose from men "unintentionally confirming to certain traditional and largely moral practices... whose significance men usually fail to understand and whose validity men cannot prove". To better understand Hayek's conclusions, one must also properly understand his view of the nature of knowledge and of the essence of an economic system. Essentially, Hayek believed that knowledge is (1) widely dispersed, (2) subjective, and (3) often tacit. The dispersal of knowledge means that relevant economic knowledge must be decentralized to a significant extent. There is no knowledge which is equally accessible to, and equally-well understood by, all persons. Most relevant to our actions is our "concrete and often unique knowledge of the particular circumstances of time and place" (The Constitution of Liberty, 1960, p 156). Much of the information that cultural rules contain is tacit knowledge, not consciously and precisely transmitted through clear intentional instructions.

Simultaneously, Michael Polanyi argued that "while tacit knowledge can be possessed by itself, explicit knowledge must rely on being tacitly understood and applied. Hence all knowledge is either tacit or rooted in tacit knowledge. A wholly explicit knowledge is unthinkable."

From Hayek's point of view, the market process and cultural evolution are distinct processes, but very closely related. The emergence of private property and competitive markets leads to the corresponding increase of individual liberty, which characterizes life in the extended order. The extended order must be seen as the product of a non-rational process. This can also be seen in Hayek's criticism towards analysing and evaluating general human behaviour with purely scientific and empiric data. 
Hayek considered "scientism" to be appropriate for natural sciences such as physics or chemistry. But human behaviour is often irrational. Humans often do things unconsciously, moreover people constantly learn, and therefore change their behaviour. Consequently, Hayek states that those who give too much relevance to man's rationality, often tend to believe in centralized and egalitarian structures such as socialism. Hayek rejected "constructivism", the assumption that 'since man himself created the institutions of society and civilization, he must also be able to alter them at will'.

Moreover, Hayek defined economics as a "metatheory" on how to discover and use different means for different purposes. For this, Hayek used the term "catallactics" to describe "the order brought about by the mutual adjustment of many individual economies in a market". The term catallactics was initially introduced by Ludwig von Mises. The laws of catallactics are no value judgments, but aim to be exact, objective and of universal validity. Hayek was dissatisfied with the usage of the word "economy" because its Greek root, which translates as "household management", implies that economic agents in a market economy possess shared goals.

An "economy", in the original sense of the word in which a household or an enterprise can be called "economies", is a combination of activities used to achieve a unitary plan, a shared common goal, which is hardly the case for what nowadays is considered a (national or world) "economy". Unlike a household, the market order serves no such single order of ends. Thus, what is commonly called a "national economy" is not "a single economy" (with one unitary plan and common goal) but a network of many interlaced economies. Instead, Hayek derived the word "Catallaxy" (from the Greek verb katallasso which meant "to exchange" and "to change from enemy into friend") to better describe the "market place". Hayek stated that the market order consists of innumerable individuals, individually pursuing their own aspirations, and each person demonstrates his or her temporary ranking of ends through the choices made and actions taken. 


\section{THE ROOTS OF SPONTANEITY AND FREE MARKET} THINKING

As we indicated, Friedrich August von Hayek made several crucial contributions to economics and social thought. However, if one specific concept had to be identified which had a significant impact, not only on Austrian school economists and libertarian philosophers, but also on mainstream academia, one would probably have to name the 'spontaneous order'. (Sandefur, 2009) It is usually Hayek who is associated with the 'revival' of the term 'spontaneous order', for giving it its name and for thoroughly developing its conceptual structure. (Bladel, 2006)

Norman Barry argues that even though the idea had already emerged in the medieval period, it is closely associated with several figures of the 18th century, in particular writers related to the Scottish Enlightenment such as Bernard Mandeville, David Hume, Adam Ferguson, and Adam Smith. Some economists state that in his famous 'Wealth of Nations', Adam Smith had already defined his idea of 'spontaneous order' with the term "the invisible hand", referring to the concept of many individuals buying and selling in a market place. At a later stage, we will explain the significant difference between Smith's "invisible hand" and the truly spontaneous interplay described by Polanyi and Hayek in their concepts of spontaneous order.

However, prior to Polanyi and Hayek, also Adam Ferguson used a phrase in his 'Essay on the History of Civil Society', which was later taken up by Hayek, stating:

“...that the crowd of mankind, are directed in their establishments and measures, by the circumstances in which they are placed; and seldom are turned from their way, to follow the plan of any single projector. Every step and every movement of the multitude, even in what are termed enlightened ages, are made with equal blindness to the future; and nations stumble upon establishments, which are indeed the result of human action, but not the execution of any human design." (Ferguson, 1767) 
In the 19th century the idea was pursued by several great minds, including Frederic Bastiat and Gustave de Molinari (1861, 1863) in France, as well as Herbert Spencer in England.

\section{Hayek vs Polanyi on the Spontaneous Order: Who said it first, when \& why?}

Hayek believed that socialist calculation and central planning were impossible, mainly due to the fact that no collectivist economy could be able to make the appropriate dynamic adjustments which would naturally occur in a free market economy. However, one may argue that Hayek was referring to an important economic issue, but without being truly aware of the broader implications of his argumentation for social theory. Thus, some scholars argue that the Hungarian scientist and philosopher Michael Polanyi was possibly second in criticizing socialism, but first to place this criticism in the proper context of spontaneous order. In the last years, several historians and philosophers argued that Hayek's role on this topic was only equal or even secondary to that of Michael Polanyi. For example Jacobs (2007) argues that Michael Polanyi had not only made use of the idea and term 'spontaneous order' but that he was the first to use the actual precise term "spontaneous order" in print. ${ }^{4}$

"When order is achieved among human beings by allowing them to interact with each other on their own initiative - subject only to the laws which uniformly apply to all of them - we have a system of spontaneous order in society." Michael Polanyi, The Logic of Liberty (1951)

It is obvious that Hayek and Michael Polanyi were of like mind on several issues. However, one can neither define Hayek as a persistent follower of Polanyi, nor vice versa. Struan Jacobs argued that there are numerous differences between both thinkers. For

\footnotetext{
${ }^{4}$ A provocative but interesting article with further details is Jacobs' "Spontaneous order: Michael Polanyi and Friedrich Hayek" (2007)
} 
example, Jacobs stated that for Hayek the characterisation of 'spontaneous order' involves different types of freedom to those advanced by Michael Polanyi. Hayek (usually) portrays spontaneous order as a single entity, which is equivalent to free society as a whole - the free-catallactic society. On the contrary, Michael Polanyi is disposed to conceive of spontaneous orders as sub-units or components within free society as a whole (Jacobs, 2007). Both departed from one another concerning the implications in terms of organization of science, as Polanyi focused on the notion of public liberty while Hayek's emphasis was rather on individual freedom. Polanyi's notion of public liberty can be associated with highlighting the importance of traditions as guides for individual behaviour.

Struan Jacobs stated that Friedrich Hayek and Michael Polanyi corresponded with each other for the best part of thirty years, sharing interests that included science, social science, economics, epistemology, history of ideas and political philosophy. However, as Jacobs believed: "both were committed Liberals but with different understandings of liberty, the forces that endanger liberty, and the policies required to rescue it." Struan Jacobs emphasized on (presumable) differences between Hayek and Polanyi, focusing in particular on three aspects, believing that:

1.) Polanyi had assumed that socialism was economically impossible whereas Hayek did not.

2.) Polanyi was a major influence on Hayek's idea of spontaneous social order, having explored the topic (in articles written in 1941 and 1948) before Hayek did.

3.) It is actually Michael Polanyi who coined the term "spontaneous order."

While appreciating the differences between Polanyi and Hayek, the author of this paper does not agree with Jacobs on several of his findings which often seem to lack objectivity and differentiation. Thus, we will use the above-mentioned statements for a more detailed, alternative interpretation of the Hayek-Polanyi relationship.

Jacobs (1999) claimed to have detected a crucial difference between Hayek and Polanyi in their attitude towards socialism 
and centralized planning in general, arguing that Hayek would have considered "economic centralized planning as feasible, though at the price of liberty..." whereas "Polanyi for his part was claiming it to be economically impossible" (p. 117). We claim this statement to be incorrect, as Hayek supported von Mises' argument regarding the impossibility of "a real, workable socialist economy" and even further elaborated on it. In addition to von Mises' thoughts, Hayek finalized several analyses on the impossibility of socialism, for example in regards to the use and distribution of dispersed and tacit knowledge. A direct comparison of statements made by Michael Polanyi and F.A. Hayek on the impracticality of socialist planning clearly proves their agreement on this issue.

Michael Polanyi (1948) believed that a free society is regarded as one which does not engage in attempting to control what people find meaningful, and a totalitarian society is regarded as one that does, on principle, attempt such control. These statements show no discrepancy with the general thoughts of Hayek, stated in his 1935 "The Present State of the Debate" in Collectivist Economic Planning:

"The essential thing about the present [unplanned] economic system is that it does react to some extent to all those small changes and differences which would have to be deliberately disregarded under the [planned] system" (pp. 212-13)

Hayek concluded that a planned socialist economy would never be able to cope with the speed and precision of an unplanned/ free market economy. The planned economy must always be less efficient than the free market. Consequently, central administration makes a reasonably efficient allocation of resources and timely rate of production "strictly impossible." Moreover, Hayek actually pronounced this point to Polanyi himself. While Hayek never responded publicly to Michael Polanyi's critique, he did address certain disagreements in their private correspondence, for which the following letter to Polanyi, dated 15 November 1948, can be seen as an example. In it, Hayek wrote: 
"I have read with the greatest interest your new article on planning in the last Manchester School. Of course I agree with you that planning of the kind that the planners imagine is just impossible. I have argued this many times and I believe even hinted at the point which you now so brilliantly elaborate ... there is no difference between us on this point, and ... your argument beautifully supplements mine. ... I do not believe there is any contradiction between the argument that planning is impossible and my argument in the "Road to Serfdom" that an attempt in that direction produces something altogether different from what the planners expect."

Thus, we may conclude that Hayek was as much convinced of the impossibility of socialism as Polanyi was. In his "Against Polanyi-Centrism: Hayek and the Re-emergence of Spontaneous Order" (2006), John P. Bladel states that the only major difference between both is that Hayek's public statements on the matter preceded Polanyi's by over a decade.

Bladel assumes that Polanyi's possible misinterpretation of Hayek could have been caused by Polanyi not properly distinguishing between the ideas of Frank Knight on the one hand, as well as Hayek and von Mises on the other hand. Frank Knight (1936) had generally accepted socialism as an economically feasible system, believing that a collectivist economy would face no problems not already faced by capitalist ones. For Knight, ethical considerations, not economic ones, were obstacles to the socialist utopia. Bladel (2006) believes that Polanyi wrongly assumed von Mises and Hayek to share Knight's views, using "as evidence" the fact that both Hayek and von Mises changed the focus of their critiques to the ethics of collectivism rather than the pure economics of socialism. However, Hayek and von Mises had simply tried to expand their critique to any centralized planning and any form of collectivism. Socialist planning had already been discredited as an economic system in the minds of Mises and Hayek (1944). By highlighting the correlation between economic centralization and political totalitarianism, Mises and Hayek intended to show the general, both moral and economic, threat of any type of interventionism and collectivism. Once the differences between Knight on the one hand and Mises-Hayek on the other hand are clearly shown, one 
can see that Hayek and Polanyi were in general agreement on the impossibility of a 'rational socialist economy'.

It can also be concluded that by looking at Hayek's writings from the 1930s, he had already explicitly addressed the subject of spontaneous social orders in some of his articles such as in "The Trend of Economic Thinking" (1933, p. 25). In it, Hayek had defined the economic system as "the product of a highly complicated organism which we could only hope to understand by the intense mental effort of systematic inquiry" (p. 19), by giving credit to Hume and Smith for being among the first to have seen this fact.

Moreover, Hayek stated that such unplanned social coordination has never been "given a title which would secure it an adequate and permanent place in our thinking" (p. 27). Hayek, also assumed that even Adam Smith's concept of an "invisible hand" was an inappropriate metaphor as it makes the mistake of attributing specific intentions to the market participants/ actors which did not exist. Instead, it is the spontaneous interplay of individual actions that leads to the formation of institutions. Consequently, Hayek confirms von Mises' approach that one should categorize society as "an organism and not an organization" (p. 27).

\section{Caldwell, Bladel and Forget on the Roots of Hayek's Concept}

The impact of the Scottish Enlightenment on F.A. Hayek's thought has been mentioned, and the relevance of Hayek's teacher, L. von Mises, is also well-known. The missing piece of the puzzle, though, is Carl Menger. Hayek returned to the founding father of Austrian economics in the early 1930s when Hayek edited several volumes of Menger's important economic writings, also writing on Menger's life and thoughts in Economica in 1934. The influence of Menger's social science thoughts on Hayek can be found throughout Hayek's later writings, for example in his "The Trend of Economic Thinking". Hayek combined his thoughts on spontaneous order with his critique of socialist planning schemes, for example in his edited volume Collectivist Economic Planning in 1935. Hayek criticized the central planners' engineering mentality: 
"A social scientist needs the special training of the economist to see [that] the spontaneous forces which limit the ambitions of the engineer themselves provide a way of solving a problem which otherwise would have to be solved deliberately." (Hayek 1935, p. 8)

Hayek's thought turned to spontaneous order in the 1930s under the positive influence of Adam Smith, Carl Menger, and Ludwig von Mises, and while strongly rejecting the equilibrium theory and the socialist calculation debate. Hayek stated that complex social problems were solved spontaneously in a way that could not be duplicated or surpassed by methods of rational control (pp. 25-26). Hayek wondered if "such a [centrally planned] system will ever even distantly approach the efficiency of a system where the required changes are brought about immediately by the spontaneous action of those immediately concerned" (1948b, p. 187). Further reference to spontaneous social forces and against interventionism had already been made by Hayek in his 1939 piece "Freedom and the Economic System" as well as in his 1941 article "The Economics of Planning."

Bladel states that Hayek's writings do not show a major direct influence from Michael Polanyi, as the beginning of Polanyi's spontaneous order thought can only be traced back to the year 1941 (Bladel, 2006) Hayek was repeatedly referring to the complexity of social phenomena and spontaneous order processes for almost a decade before Michael Polanyi's "Growth of Thought in Society" (published in 1941). By either not knowing, or by ignoring F.A. Hayek's early works, Jacobs mistakenly attributed priority to Polanyi's spontaneous order theory. Thus, based on the historic documents stated by Bladel, F.A. Hayek preceded Michael Polanyi both in criticizing socialist economic planning as impossible as well as in addressing the subject of spontaneously forming social orders.

\section{Wilhelm Röpke - The True Inventor of Today's Spontaneous Order Theory?}

However, Evelyn L Forget states that neither Hayek nor Polanyi were the first to use the term "spontaneous order", as already in 
the nineteenth-century the English philosopher John Stuart Mill referred to "spontaneous order" in his writings (Forget, 2001). There is no direct proof that Mill's use of the term led to its reintroduction into the used language. To see who had influenced whom, one may also consider that Hayek had named several twentieth-century contemporaries who he defined as pioneers in the study of social order, but without considering Michael Polanyi one of them. Instead, in his 1964 article "Kinds of Order in Society" Hayek pointed to Walter Eucken:

"The concept of order has recently achieved a central position in the social sciences largely through the work of Walter Eucken and his friends and pupils, known as the Ordo-circle from the yearbook Ordo issued by them." (1964a, p. 457)

Eucken and the ordo-liberals gave great relevance to the concept of order, and Eucken worked with Hayek in building up the Mont Pèlerin Society and promoting the ideals of classical liberalism (Hayek 1983, p. 190). However, the ordo-liberals were not truly spontaneous social order theorists, and Hayek called them followers of "a restrained liberalism". Eucken believed that one "cannot just let economic systems grow up spontaneously.... The economic system has to be consciously shaped." (Eucken 1951, pp. 314-15). Hayek respected Eucken, although the Austrian considered the ordo-liberal perspective as too inclined towards rationalist constructivism to properly embrace the idea of a truly spontaneous order. Bladel argues that it was neither Hayek, nor Polanyi nor Eucken, but Wilhelm Röpke, who first named 'spontaneous order' in print. In the first edition of his textbook, printed in 1937 but not translated into English until 1962 (Economics of the Free Society), Wilhelm Röpke explained that the market economy is a "spontaneous order" rather than a "commanded order," and that the "anarchy" of the capitalist system would ultimately be superior to the command system advocated by collectivists (pp. 4-5). Röpke used the term in his articles and books throughout the 193040s. Röpke was influenced by von Mises and Hayek, but he also frequently cited the Spanish philosopher José Ortega y Gasset, who himself proposed "spontaneous social action" (Ortega y Gasset 1932, pp. 120-21). Thus, the general concept and meaning of 'spontaneous 
order' seem to have developed within the classical liberal tradition before Michael Polanyi's key articles on "dynamic" and "spontaneous" order (1941, 1948, 1951).

In The Logic of Liberty (1951,) Michael Polanyi stated that:

"There is a wide range of such systems in nature exhibiting similar types of order. They have been called systems of "dynamic order" by Kohler, whose designation I followed in an earlier writing; but I think it will be simpler to refer to them as systems of spontaneous order." (Polanyi, p. 154)

Caldwell (2000) defined an alternative interpretation of Polanyi's influence on Hayek. Even if Polanyi had a certain influence on Hayek's later thoughts, there are several indications to doubt that it was strong and crucial. If Hayek borrowed from Polanyi, it seems like he limited his borrowing to Polanyi's terminology, not his concepts: The concepts of polycentrism, tacit knowledge, and discovery had all already been indicated in Hayek's early works, but Hayek seems not to have had the appropriate vocabulary to express them effectively. Thus, it is argued that Polanyi helped to make explicit what was previously only tacit in Hayek's thought. In a letter to Hayek dated February 19, 1963, Michael Polanyi wrote: "I hope that you will find your ideas of the organization of fragmentary knowledge confirmed and generalised in my treatment of the Republic of Science." Hayek's citation of Michael Polanyi in relation to spontaneous order in The Constitution of Liberty (1960, p. 160) does not place the term "spontaneous" in quotes, but rather, "polycentric order."

\section{$\mathrm{V}$ \\ SIMILARITIES AND DIFFERENCES: HAYEK AND M. POLANYI ON KNOWLEDGE}

With the publications of Hayek's trilogy Law, Legislation and Liberty (1973-1979), Norman Barry's Hayek's Social and Economic Philosophy (1979), George Shackle's Epistemics and Economics (1972), as well as Michael Polanyi's The Logic of Liberty (1951), the discussions and the precision of the term "spontaneous order" have constantly 
evolved. Michael Polanyi, whose work also paved the way for those of Thomas Kuhn and Karl Popper, argued that tacit knowledge - tradition, inherited practices, implied values, and prejudgments - is a crucial part of scientific knowledge.

Hayek and Polanyi agreed that knowledge must never be artificially concentrated into a single entity at the hierarchical top, as central government never has rational means of figuring out which goods and services are the most crucial and desired ones for the population. Also in regards to science, both agreed that no central government can define what the optimal level of research is. Science and technologic advancement progress best, when free, talented individuals used their eagerness to experiment, their enthusiasm and knowledge to exercise their minds independently without any ideological and governmental constraints. Many great thinkers and inventors were opposed by government and had to deal with governmental barriers. Hayek invalidates the idea that a single central committee can adequately accumulate a greater level of knowledge than the market as a whole, or at least a sufficient amount to create a more efficient economic order than a free market does. The key elements of Hayek's definition of the nature of knowledge are the definitions that knowledge is widely dispersed, subjective, and often tacit. Stating that information must be widely dispersed refers to the belief that crucial and detailed economic knowledge must always be decentralized to a significant extent. Crucial to man's actions is the "concrete and often unique knowledge of the particular circumstances of time and place" (1945).

Similarly, Michael Polanyi stated that the amount of knowledge individuals obtain from thorough, directly available evidence to us, is limited. Thus, most of our beliefs would continue to be obtained at second hand through trusting others, and in the great majority of cases our trust is placed in a few people who have a certain academic or social standing or who have otherwise achieved a high reputation. Polanyi said that one needs to "reconsider human knowledge by starting from the fact that we can know more than we can tell", and that discoveries are made by pursuing possibilities suggested by existing knowledge. 
For Polanyi, all communication relies to a noticeable extent on evoking knowledge that we cannot tell, and that all our knowledge of mental processes, such as feelings or conscious intellectual activities, are based on a knowledge which we cannot clearly describe. As stated, Polanyi believed that tacit knowledge can be possessed by itself, but explicit knowledge must always rely on being tacitly understood and applied. Consequently, all knowledge is either tacit or rooted in tacit knowledge, because a fully explicit knowledge is unthinkable. For Polanyi, personal participation must be seen as the universal principle of knowing. Moreover, Polanyi explained that once order is achieved among human beings by allowing them to interact with each other on their own initiative, then we have a system of spontaneous order in society. (Polanyi, 1951)

Michael Polanyi argued: "I shall reconsider human knowledge by starting from the fact that we can know more than we can tell.... all our knowledge of mental processes, like feelings or conscious intellectual activities, is based on a knowledge which we cannot tell.... Discoveries are made by pursuing possibilities suggested by existing knowledge."

Regarding the term "tacitness", Hayek mainly agreed with Polanyi that man is able to do many things without being able to actually explain how to do them from a purely theoretical, e.g. physical, point of view. Hayek considers many human actions and perceptions as steered by "movement patterns" and "ordering principles". Even more complex is the example of languages, as languages are seen as a system of learned rules evolving spontaneously. Hayek also declares that comprehensibility of human interactions is the basis for social sciences and consequently also for economics. Moreover, Hayek states that there is a "meta-conscious" level, a supra-conscious process, crucial for communication, as several rules simply cannot be explained with purely conscious conceptualization. ${ }^{5}$

5 The Spanish economist Jesús Huerta de Soto further developed the discussed concepts of Hayek, Mises, Polanyi and Kirzner in his work Socialism: Economic Calculation and Entrepreneurship (2010) in which he presents the chart of the next page (p. 40). 


\begin{tabular}{ccc}
\hline & Types of Knowledge & \\
\hline Source/ defined by: & Type A (entrepreneurial) & Type B (scientific) \\
\hline Oakeshott & Practical & scientific / technical \\
\hline Hayek & Dispersed & centralized \\
\hline M. Polanyi & Tacit & articulated \\
\hline Mises & individual events & categories / groups \\
\hline
\end{tabular}

(from Huerta de Soto, op. cit., p. 40)

Hayek criticized that mainstream economists intend to formulize and mathematize all economic processes and developments considering their approach as very theoretical and unrealistic, since humans constantly learn and change their behaviour and preferences, naturally intending to create a market based on a spontaneous order. Thus, real competition is a competitive process, a series of competitive acts and steps taken by competing enterprises/entrepreneurs, influencing prices as well as service and product quality. He pointed out that an efficient economic order and growth cannot be achieved in a market despite the lack of centralized steering, but in fact, it can only be assured due to the absence of a centrally planned economy.

Moreover, Hayek said that the market process is mainly a process in which participants discover relevant information. The economy is seen as a mechanism which generates and distributes knowledge, characterizing economics as the study on the utilization of knowledge in society. Thus, the economic problem of society is not a problem of how to allocate given resources, but a problem of utilization of knowledge which is not given to anyone in its totality. In a free society, countless individuals managing their own affairs end up cooperating without realizing it, thanks to the choices they make based on their limited information.

At a later stage, this aspect was also analysed by the Austrian School economist Israel M. Kirzner (1973) who argued that in reality, competition is a constant rivalrous process, saying that there cannot be any competition in constant equilibrium ${ }^{6}$, as

6 The book Competition and Entrepreneurship (1973) by Israel M. Kirzner can be seen as the further development of Hayek's ideas in regards to a dynamic, constantly changing market. 
stable equilibrium is not an action. Profit and losses are essential tools to coordinate the allocation of scarce resources. Hayek believed that economic rationality is a product of markets, as people learn from the market place, instead of entering the market already being fully informed. Markets reflect consumers' subjective valuations, and with economic calculation entrepreneurs constantly intend to adjust to the (changing) demands of consumers. In a free market, no-one is able to tell the consumer what to buy. Each of us has his/her own subjective preference scale. Whenever we trade, we create unequal valuations. People subjectively value costs. Due to the profit motive, entrepreneurs always intend to supply the most urgent desires of customers. Losses are mainly the result of a lack of alertness, or simply of bad judgement. This argument shows similarities to Michael Polanyi's idea that "personal participation is the universal principle of knowing."

VI

SIMILARITIES AND DIFFERENCES: POLANYI ON SOCIALISM, SCIENCE AND POLICENTRICITY

Jacobs states that also management theory provided Polanyi with a vocabulary and ideas enabling him to better understand liberal science and society. Polanyi's constructive use of terms and understandings from management has barely been touched on in literature, not mentioning those management theorists that likely helped Polanyi to deepen and sharpen his understanding of liberal society and science. In particular Michael Polanyi essays - "Collectivist Planning" (1940), "The Growth of Thought in Society" (1941) and "The Republic of Science" (1962) are crucial to prove how management ideas aided the development of his understandings of science and society. He paid specific attention to 2 different forms of coordination of human actions: those managed or planned, as well as those non-managed nor supervised. 


\section{Polanyi, the USSR and the Impossibility of Socialism}

In 1928, Polanyi started to make trips to the former Soviet Union, giving scientific presentations while trying to learn more about the Soviet political system, its society and culture. His 1935 essay "USASR Economics - Fundamental Data, System and Spirit" (reproduced under the title "Soviet Economics - Fact and Theory" in his essay collection The Contempt of Freedom [1940, pp. 61-95]) explained Polanyi's view on the Soviet economy. Polanyi noted that even though industry and commerce remained government owned they were still required to "be run profitably". The state could not decide independently what goods should be produced for consumers, having to rely on business people's experience and expectation of profits (Polanyi, 1940)

Polanyi (1940, pp. 27-60) elaborated his view of science and society in the 1940 essay "Collectivist Planning". He did this in opposition to Marxist and other proponents of planning who praised the (apparent) success of the Soviet five-year plans against the apparent dysfunction of capitalist societies during the Great Depression of the 1930s. For Polanyi (1940, p. 46, n.1), the concept of central planning of research by the Soviet Government was as counterproductive as the claim for central economic planning. Totalitarians, as Polanyi (1941, p. 429-439) said, reduce social order to "the commands of the State", with executive authority steering the "co-ordination of [...] citizens".

Following the Gestalt psychologist Wolfgang Köhler, Polanyi (1941, p. 435) defined dynamic order as "an ordered arrangement resulting by spontaneous mutual adjustment of the elements". Polanyi criticised that wherever people see a well-ordered arrangement of things, they often automatically and instinctively assume that someone "intentionally placed things" in that order, not believing that such an order could develop in the free market/ a free society. Polanyi cited the market economy as an obvious example of dynamic order in society, involving producers competing against one another to maximize their profits by efficiently utilising resources which are at their disposal. Each decision taken by a producer alters the demand for, and market price of, resources, directly leading other producers to adjust their demands. 
For Polanyi, production represented a dynamic order, "because it is an arrangement of great complexity and usefulness, achieved by a series of direct lateral adjustments between individual producers making independent decisions". Common law is seen as another dynamic order, when a judge adds his decision to the existing order of judge made law, having his decision based on precedents and statutes, but possibly also considering the broad trend of public opinion. The "direct adjustments between succeeding judges", representing the dynamic order of common law, are "precisely analogous to the relationship between the consecutive decisions of individual producers acting in the same market" (Polanyi, 1941, p. 436).

\section{Cultural Heritage and Dynamic Order in Science}

Michael Polanyi's Logic of Liberty explains the tension as well as the complementarity between what he calls corporate/ hierarchical orders and spontaneous orders. Also von Mises and Hayek point out the interaction of deliberation and spontaneity. In building one's own plant one also contributes a new element in what Ludwig Lachmann calls a 'lattice-work structure of heterogeneous yet interconnected and complementary capital goods' (Lachmann, L. Capital and Its Structure).

Other Polanyi writings of the 1940s state that central planning of production in an industrial economy is impossible, as it would not provide the number of necessary economic adjustments regarding the "allocation of materials to each productive enterprise" (Polanyi, 1951, p. 111). Polanyi generalized his arguments to basically all "systems of spontaneous order" in modern society. One may argue whether a dynamic order, such as science, has a form of management or if is it entirely a matter of scientists exercising freedom to work as they please?

In "The Growth of Thought" (1943), Polanyi indicated that scientists "are not fulfilling another's instructions, elaborating details of another's scheme, as is the subordinate official's duty" in an organization. However, they are also subject to management, as 
science is also led by a certain "cultural heritage", by distinguished scientists who act as "guardians" within this dynamic order.

At a later stage of his life, Michael Polanyi described the dynamic/ spontaneous order of science as "The Republic of Science", which was also the title of an essay he published in the first issue of the journal Minerva (1962). In this article, Polanyi (1962, p. 61) referred to "the principles of organisation" that underpin the advancements of science and enable "this vast domain of collective creativity... to be effectively promoted and coordinated".

Polanyi emphasized that science cannot be managed by a rigid central authority striving to maximize the efficiency or productivity or social benevolence of research, as it would eliminate the scientists' independent initiatives. Science exemplifies the principle of spontaneous "coordination by mutual adjustment", analogous to the "coordinating functions of the market" where price signals help to adjust the market, informing suppliers of unmet demand (Polanyi, 1962, p. 56). Individual initiative is the driving, dynamic force in science, as it is up to each scientist to combine his personally acquired knowledge, which however was influenced by journal and conference literature, and knowledge acquired from discussions with his peers etc. Here, Polanyi pointed out his idea that authority in science is exercised by "influentials", however, it remains the case that scientific opinion includes all scientists, rather than "influentials" comprising a separate class with a "say-so" over the rest.

Polanyi, demonstrated that a scientist's personal participation in his knowledge, in both its discovery and its validation, is an indispensable part of science itself. As indicated, Polanyi believed that "discoveries are made by pursuing possibilities suggested by existing knowledge". Polanyi criticised the tendency to make knowledge impersonal, as it would split fact from value, and science from humanity. Polanyi described the informal and tacit elements essential to science, which includes the transmission of skills from master to apprentice, and the development of "connoisseurship". (Polanyi M. , 1974).

"I shall suggest, on the contrary, that all communication relies, to a noticeable extent on evoking knowledge that we cannot tell, and that all our knowledge of mental processes, like feelings or 
conscious intellectual activities, is based on a knowledge which we cannot tell." Michael Polanyi

\section{Polycentricity - from M. Polanyi to Elinor Ostrom}

The concept of polycentricity (often defined as a social system of many decision centers having limited and autonomous prerogatives, while operating under an overarching set of rules) was first envisaged by Michael Polanyi (1951) in his book The Logic of Liberty. Being picked-up by several philosophers, sociologists and economists, it influenced law studies (thanks to Lon Fuller (1978), Chayes 1976; Horowitz 1977), as well as urban networks studies (Davoudi 2002; Hague and Kirk 2003), and, even more importantly governance studies, thanks to Vincent and Elinor Ostrom. Elinor Ostrom, who won the Nobel Prize in economics in 2009, raised significant attention to the concept. Michael Polanyi's initial development of the concept of polycentricity was the outcome of his interest in the social conditions preserving the freedom of expression and the rule of law (Prosch 1986, 178).

Polanyi (1951) argued that the success of science was mostly due to its "polycentric organization." In such a system, participants benefit from the freedom to make individual and personal contributions, and to structure their research activities freely. Polanyi also used the concept of polycentricity as a tool to demonstrate the well-known socialist calculation problem (Lange 1938; Mises 1922). The market is seen as a polycentric system involving a web of many agents who constantly adjust their behavior to 'market demands'. Polanyi's concept of polycentricity proved to be a source of inspiration in legal studies. In this regard, Fuller (1978, 354-355) asked a very relevant question: Which legal issues should be settled in court, which should be settled by political means, and which should be left to the market? Fuller made out of the notion of polycentricity a key element in his system of justice, but it was the work of Vincent and Elinor Ostrom that operationalized it and gave it empirical substance. The concept of polycentricity, as developed by Michael Polanyi and further defined by Ostrom serves as 
an analytical framework, but also for making analogies between different complex systems. Both focused on analogies with markets; for example, Ostrom's idea of market-like interorganizational arrangements or of 'public entrepreneurship' brings market-like attributes to public administration. Also the concepts of a 'common property system', further defined by Elinor Ostrom, can be seen as a relevant progress. Ostrom's ideas provide sophisticated solutions for the privatization of possible common resources such as forests or rivers and other resources with clearly defined boundaries - and could even be feasible for negative externalities of production. Elinor Ostrom's work 'Governing the Commons' (1990) has been crucial for legal thinkers working on property rights and resource dilemmas. Elinor Ostrom believed that "...there is no reason to believe that bureaucrats and politicians, no matter how well meaning, are better at solving problems than the people on the spot, who have the strongest incentive to get the solution right." She spent significant time on investigating how communities succeed or fail at managing common pool (finite) resources such as grazing land, forests and irrigation waters. Her analyses on how communities co-operate to share resources drives to the heart of debates today about resource use. In 'Governing the Commons' Elinor Ostrom criticized that: "as long as a single center has a monopoly on the use of coercion, one has a State rather than a self-governed society."

VII

POLANYI: A LIBERAL, A KEYNESIAN, OR SOCIAL DEMOCRAT?

However, in the final section of his "Collectivist Planning" essay, Polanyi hoped that liberalism might revive itself as a dynamic philosophy. He partially criticised the views of Hayek and Ludwig von Mises for leading to the "evil consequences of free trading" while also opposing any "State enterprise", which Polanyi (1940, p. 57) described as in being contradiction of "the very principles of civilization". Planning destroys freedom, but so, Polanyi believed, does entirely free laissez faire economics. (Polanyi, 1940, p. 58) 
In several aspects Michael Polanyi was more 'constructivist' than Hayek, for which in several aspects he seems to be closer to Keynesianism than to libertarian ideas. As a scholar untrained in economics he provided an iconoclastic approach in occasionally defending either Keynesian or Hayekian ideas. Polanyi was not convinced by Hayek's conception of economics, in particular regarding Hayek's defense of laissez faire in the field of economic policy. When Polanyi read Keynes' The General Theory of Employment, Interest and Money, he was impressed by its economic policy implications. One could summarize that Michael Polanyi defended both a Hayekian conception of society and a Keynesian macroeconomic approach. Polanyi was rather in line with Hayek's conception of knowledge and emergence of novelty, which Polanyi described as a polycentric process. (Polanyi, 1945, p. 149). But Polanyi was more in line with Keynes on several politico-economic aspects, also in regards to the possibility to solve economic inefficiencies by using what Popper called 'piecemeal technology'. The fact that Polanyi further developed and combined both Hayekian and Keynesian conceptions has often been considered contradictory. In several aspects, Polanyi undoubtedly accepted state intervention to foster economic growth despite his commitment to spontaneous order and liberalism. For example. Polanyi parted ways with Hayek in regards to the usefulness of the term 'social justice'. While Hayek (1973) argued that the term 'social justice' as such is literally meaningless, Polanyi was concerned that the market system would come into conflict with certain moral values and that it may actually generate incentives undermining moral behavior (Polanyi and Prosch 1975). On the one hand, Polanyi stressed the idea that polycentricity (self-organization) is efficient compared to planning. On the other hand, he supported State intervention - in case certain constraints are fulfilled - in order to help reduce unemployment. As a liberal, Polanyi detected an important difference between private freedom and public liberty, and as an evolutionist, Polanyi disagreed with Hayek's non-teleological interpretation. Polanyi envisioned society as a network of overlapping layers of orders which are governed by two kinds of co-ordination mechanisms (spontaneous market-like vs. planned organization-like). Despite differences between the various orders within society, the system as a whole could not be maintained 
without what Polanyi calls 'public power'. Thus, unlike the invisible hand, public power 'shelters and controls' the 'economic institutions of society' (Mullins, 2013).

Further examples of dynamic social-cultural orders in Polanyi's concept (1941, p. 438) include "the social legacies of language, writing, literature and of the various arts, pictorial and musical"; crafts, including as well medicine, agriculture and manufacture; and religious and political thought. Each of these systems has a mental heritage handed down by one generation and assimilated by the next generation which will then itself strive to further develop and improve it with its own new achievements. Participants in Polanyi's 'cultural dynamic orders' intend to exercise freedom of a distinctive type which he termed "public liberty", meaning an agent is free "to act according to his own conviction". Liberty of the opposite sort - "private freedom" - leaves an agent to act as he pleases, whereas it is incumbent on those with public liberty to act according to the standards of their order and in light of its ideals. Public liberty occurs in and is sustained by dynamic orders and is ultimately for the benefit of the wider liberal society (Polanyi, 1941). Polanyi believed that "human beings exercise responsibilities within a social setting and a framework of obligations which transcend the principle of intelligence."

In this concept, the liberal state exercises supervisory authority over society, which can be seen as an inclusive dynamic order, forming "the intellectual and moral order of society" (1941, p. 429). Individuals in this inclusive dynamic order have the freedom to take "specific initiative", their actions being "determined not vertically from above - but laterally by direct contacts" (Polanyi, 1941, p. 439). The state supports "the growth of dynamic order" simply via its supervisory authority. It protects the citizens' initiatives, providing "opportunities for their exercise" and "enforces the rules which govern the interaction of the individuals". Meanwhile, the corporate orders of a liberal society are of secondary importance, for Michael Polanyi. Most of the corporate orders, indeed, are "industrial enterprises" operating in "competitive production" which itself is a dynamic order. 
VIII

\section{CRITIQUE ON HAYEK - BY POLANYI, STATISTS AND ANARCHO-CAPITALISTS}

On the one hand, opponents of capitalism criticize Hayek for (from their point of view) not providing a sufficiently detailed explanation why their concerns, that a free market system could lead to exploitation and an erosion of morality, are ungrounded. Hayek was criticised for considering capitalism to be altruistic, and therefore for overseeing a potentially destructive nature of altruism. Moreover, one may criticize Hayek's position on assuming that natural selection would always design social systems for the benefit of the group. Scientists of evolutionary biology such as Richard Dawkins, criticise Hayek's belief that human instincts would be overridden by customs transmitted by imitation. Dawkins talks about "social parasitism", stating that intense conflict of interests within groups (and also populations), are often the opposite of stable social patterns for the benefit of the group as a whole.

One the other hand, Hayek is often criticized by the anarcho-capitalistic branch of the libertarian movement, for not fully rejecting the concept of a 'State' as a public entity. Consequently, he is accused of not fully rejecting any sort of public interventionism (for example by rejecting the idea of privatizing homeland security/ national defense). In addition, it is also often argued that most economic ideas associated with Hayek, had previously been defined by other liberal and Austrian school thinkers, such as Ludwig von Mises (Mises, 1949). Even more so than Hayek, Michael Polanyi was by no means a radical libertarian, as he feared potential negative effects of an entire free market without public control. Polanyi's and Hayek's positions are partially seen as inconsistent, stating that both actually did not defend pure capitalism, but rather a "mixed economy" with too much centralization and governmental interventions. The anarcho-capitalist Hans Herman Hoppe, for example, does not consider Hayek a "classical liberal", but much rather a "moderate social democrat".

In this context, critics challenge Hayek's definition of "coercion" which is sometimes seen as unclear, inconsistent and contradictory. Hayek for example justified taxation as not being fully 
coercive if it is "...at least predictable and imposed equally on everyone". In addition, one may mention that Hayek focused on "patterns of social interaction" and that he considered himself a supporter of individualism, but critics mention that he was not consistent and stringent enough from a methodological point of view. Consequently, for embracing certain aspects of scepticism and for justifying governmental intervention in some areas, while simultaneously criticising a radical laissez-faire system, supporters of radical anarcho-capitalist ideas often criticize Hayek. Similar critique is often applied to Michael Polanyi, mostly coming from the same anarcho-capitalist libertarians.

In fact, anarcho-capitalists have dedicated significantly less time, energy and academic papers on criticising M. Polanyi than they have done on Hayek. However, as mentioned, in several aspects Michael Polanyi was more 'constructivist' than Hayek, for which in several aspects he seems to be closer to Keynesianism than to libertarian ideas. As a scholar untrained in economics he provided an iconoclastic approach in defending both Keynesian and Hayekian ideas.

Thus, as indicated, even if Hayek harshly criticised socialism, he was also far away from radical anarcho-capitalist positions. Hayek mentioned that "not... all state enterprises must be excluded from a free system". He confirmed that "there is a wide and unquestioned field for state activity", and even mentioned once (which might be seen as a contradiction to his often mentioned rejection to central planning and central designing), that in some situations "planning is required to make competition as effective and beneficial as possible". Some of these governmental intrusions can be justified, as they are very often related to either protecting the environment from its destruction by mankind, or to protecting those that cannot fully take care of themselves, such as children. Already in previous works, Hayek defended restrictions on pollution by factories, limitations on deforestations, as well as the financing of schools. However, he also added other topics to the list of aspects which would need governmental intervention, such as limits on labourer's working hours and even regarding public housing and a potential compulsory military service ("justified", if applied for everyone). 
Hayek considered government as "necessary" not only for "law enforcement" and "defense against external enemies" but "in an advanced society government ought to use its power of raising funds by taxation to provide a number of services which for various reasons cannot be provided, or cannot be provided adequately, by the market." (Hayek in Law, Legislation, and Liberty)

These services do not only include the protection against violence, epidemics, and natural forces such as floods and avalanches. Government functions shall also include "the assurance of a certain minimum income for everyone" and may finance schools and research as well as enforce "building regulations, pure food laws, the certification of certain professions, the restrictions on the sale of certain dangerous goods (such as arms, poisons and drugs), as well as safety and health regulations for production processes. "

Apart from that, Hayek believed that government should implement a system of compulsory insurance. Public, subsidized housing is seen as a useful government task, and even "city planning" and "zoning" are considered appropriate government functions. Moreover, "the preservation of natural beauty or of historical sites or scientific interest ... natural parks, nature-reservations, etc." are also considered reasonable government tasks. ${ }^{7}$

At one point, Hayek even stated that it was not crucial how big government is and whether it keeps growing, but what alone is important is that government actions fulfill certain "formal requirements": "It is the character rather than the volume of government activity that is important." From this approach, it appears that taxes were not seen as a general problem by Hayek, for which taxes cannot be seen as a general coercion by governments against the people. ${ }^{8}$

The libertarian philosopher and anarcho-capitalist economist Hans Herman Hoppe argues that not only Carl Menger, BöhmBawerk and von Mises, but also Murray Rothbard would represent the Austrian School's "trunk line", whereas Hayek and Israel Kirzner would only stand for a modified branch line of the

\footnotetext{
7 Hoppe, H. (2011) Why Mises (and not Hayek)?

8 Hoppe, H. (2013). Mythos Friedrich August von Hayek.
} 
Austrian School. ${ }^{9}$ On the other hand, even Hoppe must acknowledge that the political ideas in particular within Hoppe's so called "trunk branch" became significantly more radical: While Menger and Böhm-Bawerk still agreed that several aspects should be handled by the state, their successor von Mises said (by the end of his life) the only role a state shall play is to defend the private property and free contract order. Later on, von Mises' successor M. Rothbard even defended a completely anarcho-capitalistic system in which there is no role nor justification at all for the state.

Also when it comes to the role of the State in regards to science and research, Rothbard defended a much more radical approach. Both Polanyi and Rothbard criticized agenda-based research, as the government is essentially determining what sort of science should get done. Both argued that government will rarely be a 'neutral party' mostly being interested in a "certain outcome" of researches. The advancements of science are hampered by publicly-funded and state-controlled research processes as this always leads to the politicization of science and R\&D, such as government control of the research directions and outcomes. Consequently, publicly financed science is unduly governed by political considerations. Polanyi and Rothbard believed that science advanced best, when free, talented individuals used their eagerness to experiment, their enthusiasm and knowledge to exercise their minds independently without any ideological constraints. Also Polanyi strongly criticised the logical empiricism and positivism which dominated the philosophy of science in that era, while he believed that science cannot be managed by a rigid central authority, as this would eliminate the scientists' independent initiatives. He argued that science and any technologic advancement progressed best, when free, talented individuals used their eagerness to experiment, their enthusiasm and knowledge to exercise their minds independently without any ideological and governmental constraints. Michael Polanyi's ideas on science seem to be valid, also to properly criticise today's public interventionism with its inefficiency, bureaucracy and politicized research. Polanyi and

\footnotetext{
${ }^{9}$ Hoppe, H. (1996). Die Österreichische Schule und ihre Bedeutung für die moderne Wirtschaftswissenschaft
} 
Rothbard both detected the main problems caused by public coercion. Rothbard is fully correct in assuring that objective, efficient, non-ideological, market-driven and consumer-focused science can only be done in a free market by independent researchers. However, evaluating and comparing all analysed papers, Michael Polanyi's concepts in regards to science/ scientific research appear more detailed, skilled and balanced than the often rather general political thoughts of Rothbard on this issue.

However, we already showed that politically speaking, Polanyi defended (even) more interventionist ideas than Hayek. In his 'Full Employment and Free Trade' (1945, pp. 146-150), Polanyi combined a few laissez faire approaches with several Keynesian macroeconomics concepts, considering that governments shall annually decide the distribution of national income, and should also define the levels of monetary circulation as well as of unemployment.

Polanyi's concept of a free society differs from that of classical English liberals and even more so from most Austrian school economists. Polanyi defended subsystems as the basic units of society, in opposition to classical liberalism's ontology of individualism. His emphasis on public over private freedom indicates a further major difference.

The author of this paper believes that the "classical, truly liberal" idea of maximizing individual liberty, without ignoring the need for certain government interventions, must be seen as the realistic short- and mid-term-goal. The presented anarcho-capitalist concept of H.H. Hoppe, which asks for an order without a State on strictly natural-law premises, also called a 'private property order', can certainly be seen as an interesting long-term vision. But the entire privatization of all strategic logistic points, including ports, waterways, all natural resources and even of homeland security and national defense must be seen as challenging. Moreover, without any obligations to pay taxes, how could it be assured that (talented) children of poor parents would get a decent elementary and middle school education - and if it cannot be guaranteed, will this not lead to a significant waste of talent, also from a 'macro'economic perspective? We claim that both Polanyi and Hayek understood that 'the State' does not violate any rights by its pure existence, as 'the State' is, like all legal 
entities, only a legal fiction, and legal fictions cannot act. Acting is something that can only be done by living natural people. However, it is certainly difficult to generally differ between "mandatory public goods" and "private goods", as several goods can be defined as private goods by some and as public goods by other theorists. Consequently, the lines between public and private goods are not scientific, but heavily depend on historic and ethical views.

\section{IX CONCLUSION}

Both Michal Polanyi and F.A. von Hayek strongly emphasised on the impossibility of socialism and the superiority of a free market versus public interventionism. Both were convinced that central planning cannot be more efficient than a spontaneous order, since knowledge is dispersed (Hayek) and tacit (Polanyi). Based on all available documents, it appears that Friedrich A. von Hayek had already developed a proper concept of "spontaneous social order" before Michael Polanyi's first article on the subject appeared in 1948. It was Hayek's study of the Scottish Enlightenment philosophers and other liberal and Austrian-school thinkers, including Carl Menger, and von Mises, as well as the context of the socialist calculation debate, which led him to further investigate on the topic. It is also argued that the economist Wilhelm Röpke, had used the term "spontaneous order" several years before Michael Polanyi's corresponding papers were published. The hypothesis that also Michael Polanyi influenced Hayek seems very plausible in regards to the 1950, when Hayek further developed his concepts on complexity theory and tacit knowledge. However, from my findings, Polanyi's influence on Hayek's notion of spontaneous order does not appear to have had a crucial impact. However, although both shared similar concerns in regards to economic matters, they did not always come to the same conclusions. Polanyi's emphasis on defending subsystems as the basic units of society, and his focus on maximizing "public freedom" was quite different to the approach of Hayek. Both came to different 
conclusions in regards to the institutional character of science, and even concluded somewhat differently on the character of knowledge. Most importantly, they argued differently in regards to the ideal role of the State.

Polanyi's crucial findings have been extremely important for both science and liberalism. In particular on polycentricm and (tacit) knowledge, Polanyi's findings can be seen as ground-breaking. Personally, I believe that in regards to scientific research, Michael Polanyi's ideas were much more detailed, sophisticated and pragmatic than those of Hayek. However, in regards to their visions on economic policies and specifically the politico-economic aspects of their Spontaneous Order concepts, I consider F.A. Hayek's model as more consistent and coherent.

Also in academic discussions, criticism towards Hayek's thoughts is not only coming from those openly defending "big government", but also from those who consider Hayek's ideas as too moderate or even social democratic. The freedom of the individual and property protection rights must certainly be seen as the foundations of liberal thinking. However, even if Michael Polanyi's and Hayek's ideas on the impracticality of socialism may slightly differ, they both seem absolutely accurate to properly criticise today's public interventionism as both interpretations, from their individual perspective, detect the main problems caused by public coercion. Their analyses must be seen as extremely valuable to understand nowadays political, cultural and economic challenges. We must keep Michael Polanyi's and Friedrich Hayek's words in mind: their common criticism of socialist thinking, of the ignorant mistake (Hayek: 'fatal conceit') by ideologues believing they could deliberately create a better order for society.

In regards to the term and concept(s) of spontaneous order, the mutually reinforcing but still independent nature of both Hayek's and Polanyi's arguments have provided a thorough basis for proving the inefficiency of central planning. We may ultimately conclude that the re-emergence of the term and concept of 'spontaneous order' in the twentieth century was not the product of one mind's design but the consequence of the thoughts, concepts and actions of several great, liberal minds, including Mill, Menger, Mises, Hayek, Polanyi, Eucken, Röpke and many more. 


\section{BIBLIOGRAPHICAL REFERENCES}

Ames, B. (1989). Science and Spontaneous Order. Bowling Green, Ohio: Social Philosophy and Policy Center.

Barry, N. (1982). The Tradition of Spontaneous Order. Literature of Liberty 5: 7-52.

Bloom, A. (1987). The Closing of the American Mind. New York: Simon and Schuster.

Bladel, J. (2006). "Against Polanyi-centrism: Hayek and the Re-emergence of "Spontaneous Order"'". Quarterly Journal of Austrian Economics.

Boettke, P. (1998). "Economic Calculation: The Austrian Contribution to Political Economy." Advances in Austrian Economics, 5: 131-58.

- (1990). "The Theory of Spontaneous Order and Cultural Evolution in the Social Theory of F.A. Hayek." Cultural Dynamics, 3 (1): 61-83.

Caldwell, B. (2004). Hayek's Challenge: An Intellectual Biography of F.A. Hayek. Chicago: University of Chicago Press.

- (1997). "Hayek and Socialism." Journal of Economic Literature 35 (December): 1856-90.

Eucken, W. (1950). „Technik. Konzentration und Ordnung der Wirtschaft." Ordo 3(1)

Ferguson, A. (1767). An Essay on the History of Civil Society. London: T. Cadell, Libertyfund.

Festré, A. (2015). “Michael Polanyi's Economics: A Strange Rapprochement." GREDEG Working Papers Series. Université Côte d'Azur.

Forget, E. L. (2001). "Jean-Baptiste Say and Spontaneous Order." History of Political Economy.

Grant, K. (2007). "Tacit knowledge revisited - we can still learn from Polanyi." The Electronic Journal of Knowledge Management, Vol. 5, pp. 173-180.

Hayek, F.A. (1944). The Road to Serfdom. Chicago: University of Chicago Press.

- (1960). The Constitution of Liberty. Chicago: University of Chicago.

- (1973). Law, Legislation and Liberty, Vol. 1: Rules and Order. University of Chicago Press. 
- (1976). Law, Legislation and Liberty, Vol. 2: The Mirage of Social Justice. University of Chicago Press.

- (1979). Law, Legislation and Liberty, Vol. 3: The Political Order of a Free People. University of Chicago Press.

- (1935). Collectivist Economic Planning. London: Routledge \& Kegan Paul Ltd.

— (1933). "The Trend of Economic Thinking." Economica, 40(1): 121-137.

- (1945). "The Use of Knowledge in Society." American Economic Review XXXV, No. 4. pp. 519-30

- (1964). "Kinds of Order in Society." New Individualist Review 3(2). Indianapolis: Liberty Press, 1981. Pp. 457-66.

— (1959). “Tribute to Röpke." In The Collected Works of F.A. Hayek, Vol. IV: The Fortunes of Liberalism: Essays on Austrian Economics and Ideal of Freedom. Chicago: University of Chicago Press, 1992. Pp. 195-97.

- (1991). The Fatal Conceit: The Errors of Socialism. Chicago: University of Chicago Press.

Hoppe, H.H. (2003). Die Österreichische Schule und ihre Bedeutung für die moderne Wirtschaftswissenschaft.

- (1989). "Fallacies of the Public Goods Theory and the Production of Security." The Journal of Libertarian Studies (Vol. IX, No. 1)

- (1993). The Economics and Ethics of Private Property: Studies in Political Economy and Philosophy. Auburn: Ludwig von Mises Institute

- (2013). "Mythos Friedrich August von Hayek." Ludwig von Mises Institut Deutschland. Retrieved on 16 November 2020 from: https://www.misesde.org/2013/05/mythos-friedrich-augustvon-hayek/

- (2011). "Why Mises (and not Hayek)?" Mises Institute. Mises Daily. Retrieved on 16 November 2020 from: https://mises.org/ library/why-mises-and-not-hayek

Huerta de Soto, J. (2008). The Theory of Dynamic Efficiency. Abingdonon-Thames: Routledge Foundations of the Market Economy.

- (2010). Socialism, Economic Calculation and Entrepreneurship, Cheltenham (UK): Edward Elgar.

- (2012). Money, Bank Credit, and Economic Cycles. Auburn, Alabama. Ludwig von Mises Institute. 
Jacobs, S. (1999). "Michael Polanyi and Spontaneous Order." The Review of Austrian Economics, 11, Issue 1-2, pp 111-127

- (2007). "Spontaneous order: Michael Polanyi and Friedrich Hayek." Critical Review of International Social and Political Philosophy, 49-67.

- (2015). Management and Michael Polanyi's Thought. Emerald Group.

- (2016). Friedrich Hayek and Michael Polanyi in Correspondence. History of European Ideas, 107-130.

Kirzner, I. (1973). Competition and Entrepreneurship. The University Of Chicago Press.

- (1963). "Market Theory and the Price System." The Collected Works of Israel M. Kirzner. Liberty Fund Collection

Lachmann, L. (1978). Capital and its structure. Kansas City: Sheed Andrews and McMeel.

Mises, L. (1949). Human Action: A Treatise on Economics. New Haven: Yale University Press

- (1919). Nation, State, and Economy: Contributions to the Politics and History of Our Time. New York: New York University Press, 1983.

- (1951). Socialism: An Economic and Sociological Analysis. New Haven: Yale University Press.

Ostrom, E. (1972). “Metropolitan Reform: Propositions Derived from Two Traditions." Social Science Quarterly 53: pp. 474-493.

- (1990). Governing the Commons: The Evolution of Institutions for Collective Action. Cambridge: Cambridge University Press.

Polanyi, M. (1948). "Planning and Spontaneous Order." The Manchester School of Economic and Social Studies, 16: 237-68.

- (1951). Logic of Liberty. University of Chicago Press.

- (1940). The Contempt of Freedom. Arno Press, New York.

- (1941). "The Growth of Thought in Society." Economica, Vol. 8 No. 32 (November), pp. 428-456.

- (1945). Full Employment and Free Trade. London: Cambridge University Press.

- (1962). "The Republic of Science." Minerva, Vol. 1 No. 1, pp. 54-74.

- (1963). Letter to F.A. Hayek. Dated February 19. Hayek Archives, Hoover Institution, Stanford Calif.

- (1967). Tacit Dimension. Routledge \& Kegan Paul. 
- (1966). "The Logic of Tacit Inference", in Polanyi, M.(Ed.), Knowing and Being, pp. 138-158.

- (1974). Personal Knowledge: Towards a Post-Critical Philosophy. University Of Chicago Press.

- (1997). "Society, Economics and Philosophy", in R.T. Allen (ed.), Selected Papers. London: Transaction Publishers.

Raico, R. (1996). "Mises on Fascism, Democracy, and Other Questions." Journal / Libertarian Studies 12, no. 1

Reimers, P. (2018). "Fiat Lux and Crony Capitalism - The Impact of Monetary and Fiscal Policies in the Automobile Industry in USA and Europe from 2001 to 2010." Procesos de Mercado. Vol. 15, $\mathrm{N}^{\mathrm{o}} 2$, 2018, pp. 107-164

- (2019). "Monarchy, Democracy and Private Property Order How human rights have been violated and how to protect them." Procesos de Mercado. Vol. 16, N 1, pp. 177-212.

- (2019). "Secession, Democracy \& Human Rights." Mises: Interdisciplinary Journal of Philosophy Law and Economics, São Paulo, $7(1)$.

- (2020). “The Facets of the Enlightenment Movement from a Libertarian Perspective." Mises: Interdisciplinary Journal of Philosophy Law and Economics, São Paulo, 8(1)

Roepke, W. (1971) A Humane Economy. Indianapolis, Ind.: Liberty Fund, pp.129-36

- (1948). The Moral Foundations of Civil Society. London: Routledge.

- (1936). "Socialism, Planning, and the Business Cycle." Journal of Political Economy 44 (June): 318-38.

Rothbard, M. (1973). For a New Liberty. Macmillan Publishing, New York.

- (1962, 2004). Man, Economy and the State. Editorial Ludwig von Mises Institute

Sandefur, T. (2009). Four Problems with Spontaneous Order. Cato Unbound. Retrieved on 12 November 2020 from: https:// cato-unbound.org/2009/12/07/timothy-sandefur/four-problems-spontaneous-order

Shackle, G. (1972). Epistemics and Economics. Cambridge: Cambridge University Press. 